\title{
Was die vorming van ' $n$ eie kerkverband deur die kerk in Transvaal in 1853 "sondige verskeurdheid"?
}

\author{
J J P MÜLLER
}

Die bewoners van die gebied noord van die Vaalrivier in 1853 het vele ontberings, wat uit die Groot Trek gespruit het, agter die rug gehad. Hulle wat as welvarende inwoners uit die Oosgrensgebied weggetrek het, was byna sonder uitsondering van hulle besittings beroof en verarm. Baie families was beroof van geliefdes wat vermoor is of gesneuwel het. Hierdie ontberings en verliese het hulle verduur en gedra eerder as om onder die Britse bewind in die Kaap of elders te staan. En nou in 1853 verkeer hulle in 'n nuwe vaderland, die Transvaal.

In hierdie wordingsjare van die ZAR was ongeorganiseerdheid nog op byna elke terrein te bespeur. Verdeeldheid het helaas ook nog baie probleme geskep. Daar het ook'n gevoeligheid oor politieke en kerklike sake by die Transvaalse bewoners bestaan. Na al die ontberings het hulle skerp opvattings oor politieke en kerklike aangeleenthede gehad. Ervarings en gebeure met die Groot Trek en in Natal het ' $n$ indruk op hulle gemaak wat nie onderskat of misgekyk moet word nie. Veral waar invloed van die Britse owerheid ter sake gekom het, het hulle viervoet vasgesteek.

Nou in 1853, na al die leed en ontberings, is hulle staatkundig vry en onafhanklik. Met die Sandrivierkonvensie het die Britse regering die onafhanklikheid van die gebied noord van die Vaalrivier erken en onderneem om dit te eerbiedig.

Teen hierdie agtergrond moet die kerklike gebeure van 1853 in Transvaal gesien en beoordeel word. $\mathrm{Na}$ al die vrugtelose pogings om 'n eie predikant te bekom, het ds Dirk van der Hoff uiteindelik op 27 Mei 1853 te Potchefstroom aangekom as eerste predikant in Transvaal. Die afhanklikheid van die sinode van die Kaapse kerk het hiermee in 'n groot mate verdwyn en daarmee ook saam die moontlikheid van Britse invloed deur middel van predikante uit die Kaapse kerk. Die herderloosheid wat die Transvaalse kerk na die sinode van die Kaapse kerk toe gedwing het, was nou opgehef en gevolglik is dit te wagte en te verstaan dat daar ' $n$ verandering in houding ten opsigte van inlywing by die Kaapse sinode sou ontstaan. Inlywing by die sinode van die Kaapse kerk het in ieder geval vir die Transvalers te veel die moontlikheid van Britse invloed ingehou. Die risiko wat dit op kerklike en politieke vlak ingehou het, 
was vir die meerderheid Transvalers te groot dat hulle dit sommer goedsmoeds sou aanvaar as daar 'n ander uitweg was om herderlik versorg te word. (E A Walker, A History of Southern Africa, Longmans London 1964, bladsy 295).

Op 8 Augustus 1853 het die eerste Algemene Kerkvergadering te Rustenburg byeengekom en besluit om 'n selfstandige kerk in Transvaal te bly en ' $n$ eie kerkverband te handhaaf. Hierdie besluit was ' $n$ vanselfsprekende uitvloeisel van die oortuiging van die meerderheid lidmate van die kerk, nou dat daar ' $n$ eie predikant in Transvaal was. Die besluit beteken dat die kerk wat onder die Voortrekkers en daarna onafhanklik gefunksioneer het, al was dit onder moeilike omstandighede en grotendeels sonder 'n eie predikant, in die gebied noord van die Vaalrivier gehandhaaf word.

Die vraag is nou of hierdie besluit om ' $n$ organisatoriesonafhanklike kerk en 'n eie kerkverband te handhaaf sondige verskeuring was. Om hierdie vraag te $k a n$ beantwoord moet die volgende feite en kerkregtelike oorwegings in die oog gehou word:

1. Die besluit het gespruit uit politieke oorwegings en nie uit leerstellige of geloofsoorwegings nie. Die leer of belydenis van die Transvaalse of Kaapse kerk was nooit ter sprake nie. Die teendeel is egter waar, naamlik dat die samesprekings en onderhandelinge wat wel oor inlywing gevoer is, plaasgevind het omdat daar geen twispunte op verskille oor leer en belydenis was nie. Die punt van belang is dat die Algemene Kerkvergadering op die wyse wal gegooi het teen die politieke gevolge wat inlywing by die sinode van die Kaapse kerk na hulle oordeel uiteindelik sou hê.

2. Aansluitend by die vorige punt is dat met die besluit dit nie gaan om die ware of valse kerk nie. Die Algemene Kerkvergadering te Rustenburg het geen twyfel daaroor gehad of die Kaapse of Transvaalse kerk die ware kerk van ons Here Jesus Christus is nie. Beide kerke is die ware kerk. Die besluit gee egter uitdrukking aan die oortuiging van die Algemene Kerkvergadering dat die twee kerke wel 'n leer- en belydeniseenheid handhaaf maar organisatories onafhanklik sal voortbestaan.

3. Op staatkundige gebied was die Transvaal onafhanklik en vry en die ZAR sou hier tot stand kom. ' $n$ Onafhanklike staat met ' $n$ eie identiteit en karakter. Inderdaad is dit so dat in die lande waar die presbiteraal-sinodale vorm van kerkregering gegeld het, staatkundige grense eintlik vanselfsprekend die grense van die inheemse kerk was. Die konstituering van 'n eie kerkverband gebonde aan landsgrense in ' $n$ onafhanklike gebied is nooit as verskeuring van die kerk beoordeel nie. Selfs in afhanklike gebiede is die vorming van 'n eie kerk nie so beoordeel nie. Die ontstaan van ' $n$ eie inheemse kerk in die Kaap, organisatories 
losgemaak van die moederkerk in Nederland of die kerk in Brittanje, is nie beskou as verskeuring van die kerk nie. Die gemeentes in die Kaap het self 'n lang stryd gevoer om 'n eie kerkverband te konstitueer en organisatories onafhanklik te wees. Vir hulle was daar net so min twyfel daaroor dat die belydenis- en leereenheid ongeskonde sou bly as vir die Kerkvergadering van 1853.

4. Die Algemene Kerkvergadering het self sy optrede en besluit nie gesien as die stigting van ' $n$ ander kerk of as ' $n$ afskeuring of afsnyding van die kerk in die Kaap nie. Hulle wou kerklik onafhanklik wees en 'n eie kerkregering handhaaf maar die "band van vereniging" met die Nederduitse Gereformeerde Kerk in die Kaap behou om sodoende die belang van die kerk in "ZuidAfrika" te dien. (P B van der Watt, Die Loedolff-saak en die Nederduitse Gereformeerde Kerk 1862-1962, Tafelberg-Uitgewers 1968, bladsy 70-71.)

Uit bogenoemde is dit duidelik dat daar van "sondige verskeurdheid" nie sprake is by die besluit van die Algemene Kerkvergadering van 1853 om organisatories onafhanklik van die kerk in die Kaap te staan nie. Kerkregtelik lewer die besluit geen probleme nie en kan daar met die uitspraak van $P$ B van der Watt in die verband saamgestem word: "Hiermee het 'n afsonderlike sinodale verband van die Nederduitse Gereformeerde Kerk in die Transvaal tot stand gekom, maar van 'n afskeiding of stigting van 'n ander kerk naas die Nederduitse Gereformeerde Kerk is hier nog geen sprake nie." (P B van der Watt, a w, bladsy 70 ). Selfs die naam van die kerk was nog geen twispunt nie. ' $n$ Vraag wat wel van belang is, is of die sinodale verband eers in 1853 tot stand kom en of dit slegs gehandhaaf word? Die antwoord lê waarskynlik daarin opgesluit dat die verband dwarsdeur die Groot Trek en daarna sluimerend was maar nou in 1853 eers werklik uitkristalliseer. Dat daar reeds gedurende die Groot Trek en daarna tot 1853 ' $n$ bewustheid van kerklike onafhanklikheid bestaan het, val nie te betwyfel nie. Die herderloosheid het egter stremmend op die proses van volle selfstandigwording ingewerk.

Die kerkregtelike probleme is nie by die besluit van 1853 , om ' $n$ selfstandige kerk in Transvaal te handhaaf, te vind nie, maar die kiem van die werklike probleme is reeds hier aanwesig, naamlik die afwesigheid van die afgevaardigdes van Lydenburg. (B Spoelstra, Die Doppers in Suid-Afrika 1760-1899, Johannesburg 1963, bladsy 121). Die optrede van die gemeente Lydenburg wat op eie houtjie inskakel by die sinode van die Kaapse kerk en die optrede van persone soos ds van der Hoff, ds Frans Lion-Cachet, Smellekamp en Bührmann na 1853, lei tot die werklike probleme op kerkregtelike gebied. 